\title{
KINERJA RANTAI PASOK DI PABRIK GULA MADUKISMO DENGAN METODE SUPPLY CHAIN OPERATION REFERENCE-ANALYTICAL HIERARCHY PROCESS (SCOR-AHP)
}

\section{(Supply Chain Performance Measurment in Madukismo Sugar Factory with Supply Chain Operations Reference-Analytical Hierarchy Process (SCOR-AHP) Method)}

\author{
Kamila Anindita, I Gusti Agung Ayu Ambarawati dan Ratna Komala Dewi \\ Program Studi Agribisnis Fakultas Pertanian Universitas Udayana \\ J1. PB. Sudirman Denpasar, 80223, Bali, Indonesia \\ E-mail: kamila.andt@student.unud.ac.id
}

Diterima 11 Oktober 2019, disetujui 22 Mei 2020

\begin{abstract}
ABSTRAK
Pabrik Gula (PG) Madukismo didirikan pada tahun 1955 berlokasi di Kabupaten Bantul yang masih beroperasi hingga saat ini dan berperan penting dalam pemenuhan kebutuhan gula di Provinsi Daerah Istimewa Yogyakarta. Permasalahan yang dialami PG Madukismo terkait rantai pasok adalah keterbatasan areal budidaya tebu dan kualitas tebu yang diterima pabrik. Penelitian yang dilakukan di PG Madukismo bertujuan untuk mengidentifikasi mekanisme rantai pasok dan mengukur kinerja rantai pasok di PG Madukismo. Metode Analisis menggunakan metode Supply Chain Operations ReferenceAnalytical Hierarchy Process Method (SCOR-AHP). Berdasarkan hasil penelitian, mekanisme rantai pasok di PG Madukismo terdiri dari (1) struktur rantai pasok yang dimulai dari pengaturan jadwal tebang oleh bagian tanaman hingga penjualan gula oleh bagian pemasaran; (2) proses bisnis berupa sistem bagi hasil dengan persentase 66\% bagian petani dan 34\% bagian PG Madukismo; (3) sumberdaya rantai pasok berupa kapasitas giling 3.500 TCD serta teknologi budidaya dengan sistem Reynoso dan mekanisasi; (4) manajemen rantai pasok berupa kesepakatan kontraktual dengan petani. Kinerja rantai pasok di PG Madukismo berdasarkan metode SCOR-AHP pada tahun 2018 secara keseluruhan tergolong baik dengan nilai $80,82 \%$ pada petani (pemasok) dan 93,32\% pada pabrik. Alternatif solusi yang diberikan adalah meningkatkan standar pabrik dalam kategori pemenuhan bahan baku dengan cara memperketat aturan dalam standar kategori tebu bersih yang dipasok dan melakukan sortasi agar hanya batang tebu saja yang tergiling, serta meningkatkan kerja sama dengan petani tebu pola kemitraan dengan cara mendekati para pamong desa.
\end{abstract}

Kata Kunci: AHP, kinerja rantai pasok, SCOR, tebu

\section{ABSTRACT}

Madukismo Sugar Factory (SF) established in 1995, it is located in Bantul Regency and still operating until now that plays an important role in fulfilling sugar needs in the Special Region of Yogyakarta Province. Problems that Madukismo SF faced about the supply chain are limited cultivation area and the quality of sugarcane that the factory received. Supply chain performance measurement is needed to know about the factory's condition and do the controlling. The research was conducted at Madukismo SF aims to identify the mechanism of the supply chain and to measure the supply chain performance using SCOR-AHP method. Based on the research results, the mechanism of supply chain in Madukismo SF consists of (1) supply chain structure that starts from organizing harvest schedule by plant department to selling the sugar that organized by marketing department; (2) business process on the form of profit-sharing system with percentage $66 \%$ for farmers and $34 \%$ for Madukismo SF; (3) 
supply chain resources in the form of a milling capacity 3.500 TCD then a cultivation technology with Reynoso system and mechanization system; (4) supply chain management in the form of a contractual agreement with farmers. Performance of supply chain in Madukismo SF based on SCOR-AHP method in 2018 overall in the good category with score 80,82\% for farmers (supplier) and $93.32 \%$ for the factory. Alternative solutions provided are to increase factory standards in the category of raw material fulfillment by tightening the rules in the standard categories of clean sugar cane supplied and sorting so that only sugar cane is ground and increasing cooperation with sugar cane farmers in partnership by approaching the village officials.

Keywords: AHP, Supply Chain Performance, SCOR, sugar cane

\section{PENDAHULUAN}

Salah satu perubahan paradigma yang paling signifikan dari manajemen bisnis modern adalah bahwa persaingan bisnis yang terjadi tidak lagi antar perusahaan secara individual, melainkan persaingan antar rantai pasok (Lambert and Cooper, 2000). Perusahaan untuk dapat bertahan dalam perkembangan dan perubahan kondisi pasar perlu meningkatkan kinerja perusahaan. Kinerja perusahaan merupakan tingkat pencapaian hasil dalam rangka mewujudkan tujuan perusahaan (Hartati et al., 2017). Menurut Anwar (2011), penerapan manajemen rantai pasok di masa sekarang cocok untuk diterapkan karena memiliki kelebihan dimana mampu mengelola aliran barang dalam suatu rantai pasok.

Menurut Heizer dan Render (2015), manajemen rantai pasok (Supply Chain Management) menggambarkan koordinasi dari keseluruhan kegiatan rantai pasokan, dimulai dari bahan baku dan diakhiri dengan pelanggan yang puas. Sebuah rantai pasokan mencakup pemasok; perusahaan manufaktur dan/atau penyedia jasa; dan perusahaan distributor, grosir, dan/atau pengecer yang mengantarkan produk dan/atau jasa ke konsumen akhir. Tujuan dari manajemen rantai pasokan adalah mengoordinasi kegiatan dalam rantai pasok untuk /memaksimalkan keunggulan kompetitif dan manfaat dari rantai pasokan bagi konsumen akhir.

Berdasarkan Supriyatna (2017), saat ini telah banyak pabrik gula di Pulau Jawa dengan lokasi yang berdekatan ditutup oleh pemerintah karena menimbulkan persaingan tidak sehat antar pabrik. Setiap pabrik menginginkan bahan baku yang sama dari sumber yang sama sehingga terjadi perebutan bahan baku. Pabrik-pabrik gula ditutup agar pabrik gula lain dapat berproduksi secara optimum. Menurut Kertiyasa (2018), PT Perkebunan Nusantara X (PTPN X) berencana untuk menutup pabrik gula tersebut lataran tidak lagi menguntungkan. Semakin menurunnya luas areal tanaman tebu di wilayah PG Watoetoelis mengakibatkan tidak terpenuhinya pasokan bahan baku kebutuhan operasional. Akibatnya, kinerja PG Watoetoelis menurun dan menyebabkan kerugian operasional produksi perusahaan.

PG Madukismo didirikan pada tahun 1955 yang berlokasi di Kabupaten Bantul dan masih beroperasi hingga saat kini. Sebagai satu-satunya pabrik gula di Daerah Istimewa Yogyakarta (DIY), pabrik ini memiliki peran penting dalam pemenuhan kebutuhan gula di wilayah DIY dan juga sebagai perusahaan padat karya yang banyak menampung tenaga kerja dari Provinsi DIY. Aditya (2019) menyatakan bahwa kondisi yang saat ini dialami oleh PG Madukismo adalah sulitnya pengadaan bahan baku tebu. Hal tersebut dikarenakan semakin berkurangnya luasan lahan akibat pengembangan bangunan, sehingga Madukismo mendatangkan bahan baku tebu dari luar DIY. Dengan adanya pasokan bahan baku dari luar DIY, PG Madukismo hingga kini tetap mampu berproduksi. Dari uraian permasalahan di atas, maka perlu dilakukan penelitian mengenai kinerja rantai pasok di PG Madukismo dengan tujuan untuk mengetahui mekanisme serta kondisi rantai pasoknya. Penelitian terkait kinerja rantai pasok di pabrik gula telah banyak dilakukan, seperti 
penelitian Asrol (2015) yang mengukur kinerja pada agroindustri gula tebu dengan lahan Hak Guna Usaha (HGU). Namun belum dilakukan pada pabrik gula dengan pola kemitraan khususnya di PG Madukismo.

Pengukuran kinerja rantai pasok suatu perusahaan dapat menggunakan beberapa metode. Salah satu metode yang digunakan dalam mengukur kinerja rantai pasok adalah metode Supply Chain Operation Reference (SCOR) dan Analytical Hieararchy Process (AHP). Narindra (2015) menyatakan bahwa metode SCOR digunakan sebagai acuan untuk membuat rancangan pengukuran matriks kinerja rantai pasok, menganalisis kinerja, menentukan target kinerja perusahaan, dan merancang strategi peningkatan kinerja. Pertama et al., (2014) menggunakan metode AHP untuk mengevaluasi dan menentukan bobot matriks pengukuran. Dari hasil pembobotan akan diketahui matriks kinerja mana yang perlu perbaikan.

\section{METODE PENELITIAN}

Penelitian dilakukan di PG Madukismo yang beralamat di Kelurahan Tirtonimolo, Kecamatan Kasihan, Kabupaten Bantul, Provinsi Daerah Istimewa Yogyakarta. Waktu penelitian bertepatan dengan masa giling tebu di pabrik yakni dari bulan Juni 2019 - Juli 2019. Pemilihan lokasi dilakukan secara purposive.

Jenis data yang digunakan dalam penelitian adalah data kualitatif dan data kuantitatif. Data kualitatif yang digunakan dalam penelitian berupa penjelasan dari data yang diproleh di lapangan seperti pemetaan rantai pasok perusahaan, serta hasil wawancara langsung dengan pakar ahli dalam penelitian. Data kuantitatif diperoleh dari target produksi dan hasil produksi gula di PG Madukismo. Sumber data yang digunakan dalam penelitian berupa sumber data primer dan sekunder. Data primer berupa data yang diperoleh dari hasil observasi lapangan serta wawancara dengan pakar dan pihak-pihak lain yang terkait dengan rantai pasok PG Madukismo. Data sekunder meliputi data yang diperoleh secara tidak langsung dari sumbernya yang terkait dengan penelitian.

Pengumpulan data dilakukan dengan cara studi pustaka, observasi lapangan, wawancara, serta opini pakar. Adapun kriteria pakar yang turut berpartisipasi yaitu pakar yang memiliki pengetahuan dan pengalaman pada objek penelitian dan bersedia memberikan pendapat serta penilaian pada aspek yang ditanyakan. Pakar terdiri dari lima orang yaitu Kepala Bagian Tanaman, Kepala Bagian Pabrikasi, Kepala Bagian Bina Sarana Tani, Kepala Rayon Kabupaten Bantul, dan Kepala Bagian Pemasaran.

Terdapat dua variabel yang diukur dalam penelitian ini yaitu, (1) variabel makanisme manajemen rantai pasok yang diukur secara kualitatif dengan indikatornya adalah struktur rantai, proses bisnis, manajemen rantai, dan sumberdaya rantai, serta (2) variabel kinerja rantai pasok yang diukur secara kuantitatif dengan indikatornya adalah atribut kinerja reliabilitas, responsivitas, dan biaya. Kinerja rantai pasok diukur dengan bantuan software Expert Choice 11.

Tabel 1. Pembobotan perbandingan berpasangan

\begin{tabular}{ll}
\hline \multicolumn{1}{c}{ Nilai } & \multicolumn{1}{c}{ Keterangan } \\
\hline 1 & Faktor vertikal sama penting dengan Faktor horizontal \\
3 & Faktor vertikal lebih penting dibanding Faktor horizontal \\
5 & Faktor vertikal jelas lebih penting dibanding Faktor horizontal \\
7 & Faktor vertikal sangat jelas lebih penting dibanding Faktor horizontal \\
9 & Faktor vertikal mutlak lebih penting dibanding Faktor horizontal \\
$2,4,6,8$ & Nilai tengah di antara dua nilai elemen berdekatan \\
$1 /(2-9)$ & Kebalikan dari keterangan nilai 2-9 \\
\hline
\end{tabular}

Sumber: Diadaptasi dari Marimin dan Maghfiroh (2010) 
Tabel 2. Sistem monitoring indikator kinerja

\begin{tabular}{ll}
\hline \multicolumn{1}{c}{$\begin{array}{c}\text { Sistem Monitoring } \\
(\%)\end{array}$} & \multicolumn{1}{c}{$\begin{array}{c}\text { Indikator } \\
\text { Kinerja }\end{array}$} \\
\hline$<40$ & Poor \\
$>40-50$ & Marginal \\
$>50-70$ & Average \\
$>70-90$ & Good \\
$>90$ & Exellent \\
\hline
\end{tabular}

Sumber: Diadaptasi dari Sumiati (2007)

Analisis data yang digunakan dalam penelitian ini adalah analisis deskriptif untuk mengetahui mekanisme rantai pasok di PG Madukismo dengan cara memetakan struktur rantai pasok serta meninjau proses bisnis, sumberdaya rantai, dan manajemen rantai. Analisis kuantitatif dilakukan untuk mengukur kinerja rantai pasok dengan cara merancang model berdasarkan atribut kinerja dan matriks kinerja yang telah disesuaikan dengan kondisi pabrik ke dalam hirarki AHP, menilai matriks kinerja awal, memberikan pembobotan terhadap setiap hirarki yang dinilai melalui perbandingan berpasangan menggunakan skala 1-9 dengan rincian dapat dilihat pada Tabel 1. Nilai kinerja akhir diperoleh dari mengintegrasikan nilai kinerja dengan hasil pembobotan oleh pakar. Nilai tersebut kemudian dibandingkan dengan standar yang telah dijadikan acuan untuk mengetahui pencapaian kinerja dengan renrang nilai yang dapat dilihat pada Tabel 2 .

\section{HASIL DAN PEMBAHASAN}

\section{Mekanisme Rantai Pasok}

Mekanisme rantai pasok di PG Madukismo diidentifikasi berdasarkan struktur rantai pasok, proses bisnis, sumberdaya rantai pasok, dan manajemen rantai pasok.

\section{Struktur Rantai Pasok}

PG Madukismo merupakan pabrik yang berperan sebagai pengolah tebu menjadi gula serta menjadi penyangga (buffer) untuk menjamin ketersediaan guladi masyarakat. Bahan baku produksi di PG Madukismo terpenuhi oleh petani tebu rakyat dengan tiga macam pola kerjasama, yaitu Tebu Rakyat Mandiri (TRM), Kerja Sama Usaha (KSU), dan Kemitraan (KMT). Struktur rantai pasok di PG Madukismo terdiri dari tiga aliran, yaitu aliran material, aliran finansial, dan aliran informasi. Strutur rantai pasok di PG Madukismo dapat dilihat pada Gambar 1.

Sebagaimana yang telah ditunjukkan pada Gambar 1, PG Madukismo melibatkan beberapa pihak dengan peran dan aktivitas yang berbeda. Pihak yang dilibatkan dalam analisis anggota rantai pasok di PG Madukismo merupakan anggota primer dari rantai pasok. Anggota primer merupakan pihak yang terlibat langsung dengan proses bisnis yang terdiri dari petani sebagai pemasok, pabrik sebagai pengolah bahan baku, distributor/ritel, dan konsumen.

\section{Proses Bisnis}

Proses bisnis dapat dilihat melalui pola distribusi aliran material, aliran finansial, dan aliran informasi. Aliran material berupa gula SHS kualitas GKP 1. Tebu siap ditebang jika memenuhi syarat Manis Segar Bersih (MSB). Tebu layak tebang akan dibawa ke Meja Tebu dan selanjutnya dilakukan proses produksi gula. Gula yang telah dikemas akan disimpan di gudang. Terdapat dua pola dalam proses pengeluaran gula dari gudang yaitu, (1) Gula yang dijual kepada distributor menggunakan sistem Delivery Order (DO) dimana gula pesanan distributor akan diambil sendiri oleh distributor dengan membawa surat DO yang telah dikeluarkan oleh PG Madukismo dan (2) gula yang dijual kepada ritel menggunakan sistem Purchase Order (PO) dimana PG Madukismo yang akan mengantarkan barang kepada ritel.

Pada aliran finansial, siklus dimulai dari konsumen hingga petani tebu. Konsumen membayar gula yang telah dibeli dengan sistem cash and carry. kepada ritel. Pada aliran antara ritel dengan PG Madukismo, terdapat dua macam pembayaran yaitu secara tunai dan kredit. Pembayaran dari PG Madukismo kepada petani dilakukan apabila gula petani telah terjual dan dikurangi oleh pemotongan biaya yang seharusnya 


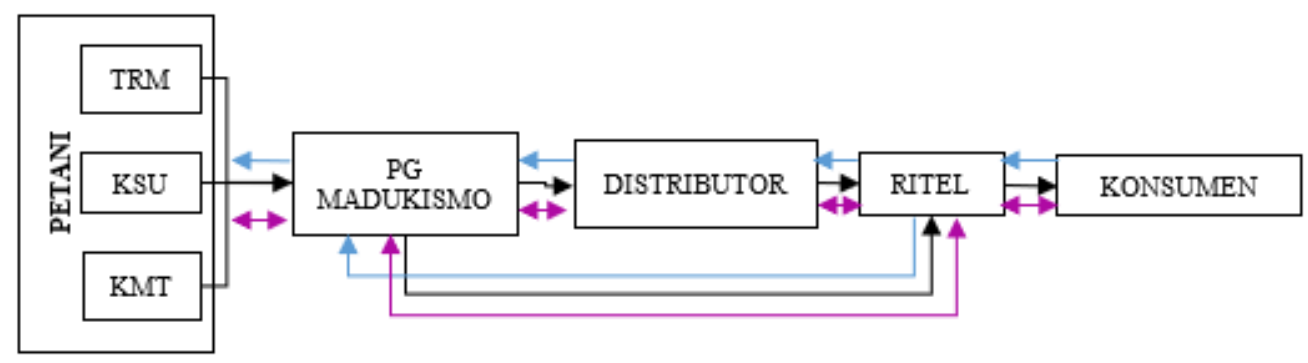

Gambar 1. Struktur Rantai Pasok di PG Madukismo Keterangan:

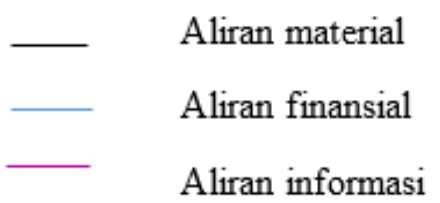

ditanggung oleh petani apabila petani memperoleh bantuan modal dari pabrik seperti biaya budidaya dan biaya tebang angkut. Petani dapat menerima uang hasil penjualan gula maksimal dua hari setelah PG Madukismo menerima pembayaran dari distributor lelang. Berdasarkan data penjualan di PG Madukismo, pada tahun 2018 harga jual gula Bulk Rp 870.501 per kuintal dan harga jual gula ritel Rp 1.109.490 per kuintal. Aliran informasi mengalir secara timbal balik dari petani hingga konsumen. Informasi disampaikan untuk menjaga kepercayaan antar anggota rantai pasok gula di PG Madukismo. Informasi yang diberikan kepada antar anggota dapat berupa informasi teknologi budidaya, masa giling, produksi, harga, dan lainnya.

\section{Sumberdaya Rantai Pasok}

Sumberdaya rantai pasok di PG Madukismo meliputi sumberdaya fisik, sumberdaya manusia dan sumberdaya teknologi. Sumber daya fisik yang dimiliki petani adalah lahan garapan yang dapat berupa sawah dengan sistem Reynoso maupun lahan tegalan dengan sistem mekanisasi. Sumber daya fisik yang dimiliki PG Madukismo meliputi pabrik seluas \pm 30 hektar. Luas lahan binaan (pola kerja KSU) seluas $314 \mathrm{Ha}$, lahan kemitraan (pola kerja KMT) seluas $1.900 \mathrm{Ha}$ dan lahan petani mandiri (pola kerja TRM) seluas $4.500 \mathrm{Ha}$. Kapasitas giling PG Madukismo 3.500 TCD dengan kapasitas produksi 3.400 TCD. Produksi gula SHS terbagi menjadi enam stasiun kerja, yaitu stasiun gilingan, stasiun pemurnian, stasiun penguapan, stasiun masakan, stasiun puteran, serta stasiun puteran dan penyelesaian. Selain itu PG juga memiliki traktor, bibit, pupuk, dan sarana produksi lainnya untuk membantu memudahkan petani dalam budidaya.

Sumberdaya manusia di PG Madukismo terdiri dari karyawan tetap dan karyawan tidak tetap. Karyawan tetap merupakan karyawan yang bekerja selama satu tahun penuh dan diberikan tunjangan gaji. Karyawan tidak tetap merupakan karyawan yang bekerja hanya pada saat musim tanam dan musim giling tiba.

Menurut Ferdiansyah (2012), terdapat dua jenis teknologi budidaya tebu, yaitu budidaya tebu dengan sistem reynoso dan sistem mekanisasi. Sistem reynoso merupakan suatu sistem bercocok tanam tebu yang menerapkan teknologi drainase dan irigasi secara efektif. Dalam sistem ini 
budidaya tebu dilakukan secara manual (menggunakan tenaga kerja manusia) pada lahan sawah. Pengolahan tanah berprinsip pada pembuatan got-got untuk penyaluran dan pembuangan air. Sedangkan sistem mekanisasi merupakan sistem budidaya yang sudah menggunaka peralatan mekanisasi seperti traktor, implement bajak, implement kairan, dan Fertilizer Applicator (FA) dalam teknis pengerjaannya. Sistem mekanisasi umumnya digunakan pada lahan kering (tegalan) dengan meminimalisir penggunaan tenaga kerja manusia. Dalam proses produksi, peralatan yang digunakan rata-rata merupakan peralatan tua, sehingga proses produksi gula di PG Madukismo masih inefisien karena untuk mengoperasikan satu mesin giling dibutuhkan kurang lebih 10 orang tenaga kerja per shift. Berdasarkan Safirin (2005), selama ini pabrik gula di Indonesia masih dikelola secara tradisional, akibatnya sebagian besar industri gula dalam negeri masih kalah bersaing jika dibandingkan dengan produktivitas industri-industri gula dari negara-negara Asia lainnya.

\section{Manajemen Rantai Pasok}

Struktur manajemen yang terdapat di PG Madukismo antara lain adalah pemilihan pemasok, kesepakatan kntraktual, dan system transaksi. Tidak ada kriteria dalam pemilihan petani pemasok di PG Madukismo. Petani sendiri yang mempercayakan tebu hasil panen mereka untuk digilingkan ke PG Madukismo. Kepercayaan tersebut diperoleh dari menjalin hubungan sosial dan karena adanya rasa saling menguntungkan si antara PG Madukismo dan petani sehingga petani tertarik untuk menjalin kerja sama dengan $\mathrm{PG}$ Madukismo. PG Madukismo juga tidak menetapkan kriteria dalam pemilihan distributor/ritel karena dalam saluran distributor, siapa saja berhak untuk membeli gula di PG Madukismo denga syarat minimal pembelian 50 ton.

Hubungan antara petani dengan PG Madukismo diatur melalui kesepakatan kontraktual. Kesepakatan yang dibuat dengan petani TRM hanya terjadi ketika masa panen telah tiba yang berisi tentang sistem bagi hasil. Untuk kesepakatan yang dibuat dengan petani KSU terdapat surat kontrak perjanjian yang berisi tentang Jaminan Pendapatan Minimal (JPM) yang ditaksir berdasarkan potensi lahan yang digarap, fasilitas sarana produksi yang akan diberikan PG Madukismo, dan sistem bagi hasil. Hubungan antara PG Madukismo dengan distributor hanya diatur berdasarkan kontrak jual beli per transaksi. Hubungan antara PG Madukismo dengan ritel bersifat kontrak perjanjian tahunan.

Sistem transaksi yang terdapat di PG Madukismo terjadi pada saat masa panen tebu tiba. Sistem transaksi dengan petani pemasok dilakukan apabila gula milik petani telah terjual, maka petani akan memperoleh hasil bersih setelah dikurangi biaya-biaya dua hari setelah gulanya terjual. Untuk pola kerja sama KMT dimana PG Madukismo diberikan wewenang untuk mengolah lahan pemilik, maka sistem transaksi dilakukan dengan dikeluarkannya Surat Perintah Tebang Angkut (SPTA) oleh Kabag Tanaman. SPTA digunakan sebagai dasar pembayaran para pekerja di kebun dan biaya transportasi pada saat panen. Sistem transaksi penjualan gula diatur melalui surat DO dan surat PO yang dikeluarkan oleh Bagian Pemasaran. Surat DO merupakan bukti transaksi yang telah dilakukan oleh distributor serta surat perintah sebagai dasar pengeluaran gula dari gudang. Surat PO merupakan bukti transaksi pemesanan gula oleh ritel.

Sebagaimana telah dijelaskan pada latar belakang, kondisi rantai pasok yang dialami oleh pabrik gula di wilayah lain tidak jauh berbeda dengan yang dialami oleh PG Madukismo, yaitu kesulitan pasokan bahan baku. Seperti pada PG Watoetoelis milik PTPN $X$ yang ditutup dikarenakan menurunnya luas areal tanaman tebu mengakibatkan tidak terpenuhinya pasokan bahan baku kebutuhan operasional, sehingga hal tersebut berpengaruh pada penurunan kinerja pabrik dan menyebabkan kerugian perusahaan. 


\section{Kinerja Rantai Pasok}

Pengukuran kinerja rantai pasok dimulai dari perancangan model yang terdiri dari atribut kinerja, matriks kinerja, dan alternatif yang dibentuk ke dalam hirarki AHP. Berdasarkan Marimin dan Maghfiroh (2010), penilaian perbandingan dikatakan konsisten jika Consistency Ratio (CR) tidak lebih dari 0,10 . Kinerja suatu rantai pasok dapat dilihat dari matriks kinerja di setiap atribut kinerjanya. Dalam penelitian ini matriks kinerja yang terverfikasi adalah pesanan terkirim penuh dan kondisi barang sempurna pada atribut reliabilitas, siklus memperoleh bahan baku dan waktu siklus pengolahan pada atribut responsivitas, serta biaya produksi pada atribut biaya. Pembobotan dilakukan dengan cara pairwise comparison terhadap matriks kinerja. Hasil pengukuran kinerja rantai pasok di PG Madukismo berdasarkan lima pakar dapat dilihat pada Gambar 2.
Berdasarkan hasil perhitungan, diperoleh nilai CR sebesar 0,02 yang berarti bahwa pakar konsisten dalam memberikan penilaian terhadap kuesioner yang telah diberikan. Matriks kinerja yang dianggap penting setelah matriks kinerja biaya produksi adalah pesanan terkirim penuh dengan bobot 0,562 . Hal ini berarti bahwa dalam rantai pasok di PG Madukismo pesanan terkirim penuh merupakan faktor yang harus diperhatikan setelah faktor biaya. Pada atribut kinerja hasil pembobotan menunjukkan bahwa reliabilitas adalah atribut kinerja terpenting dengan bobot 0,412. Hal ini berarti bahwa PG Madukismo sangat mementingkan kepercayaan konsumen. Sebagaimana menurut Ferrinadewi dan Djati (2004), apabila tercipta kepercayaan antara penyedia jasa dan konsumen, maka konsumen akan cenderung lebih loyal.

Pengukuran kinerja rantai pasok di PG Madukismo dilakukan dengan cara membandingkan nilai kinerja aktual dengan

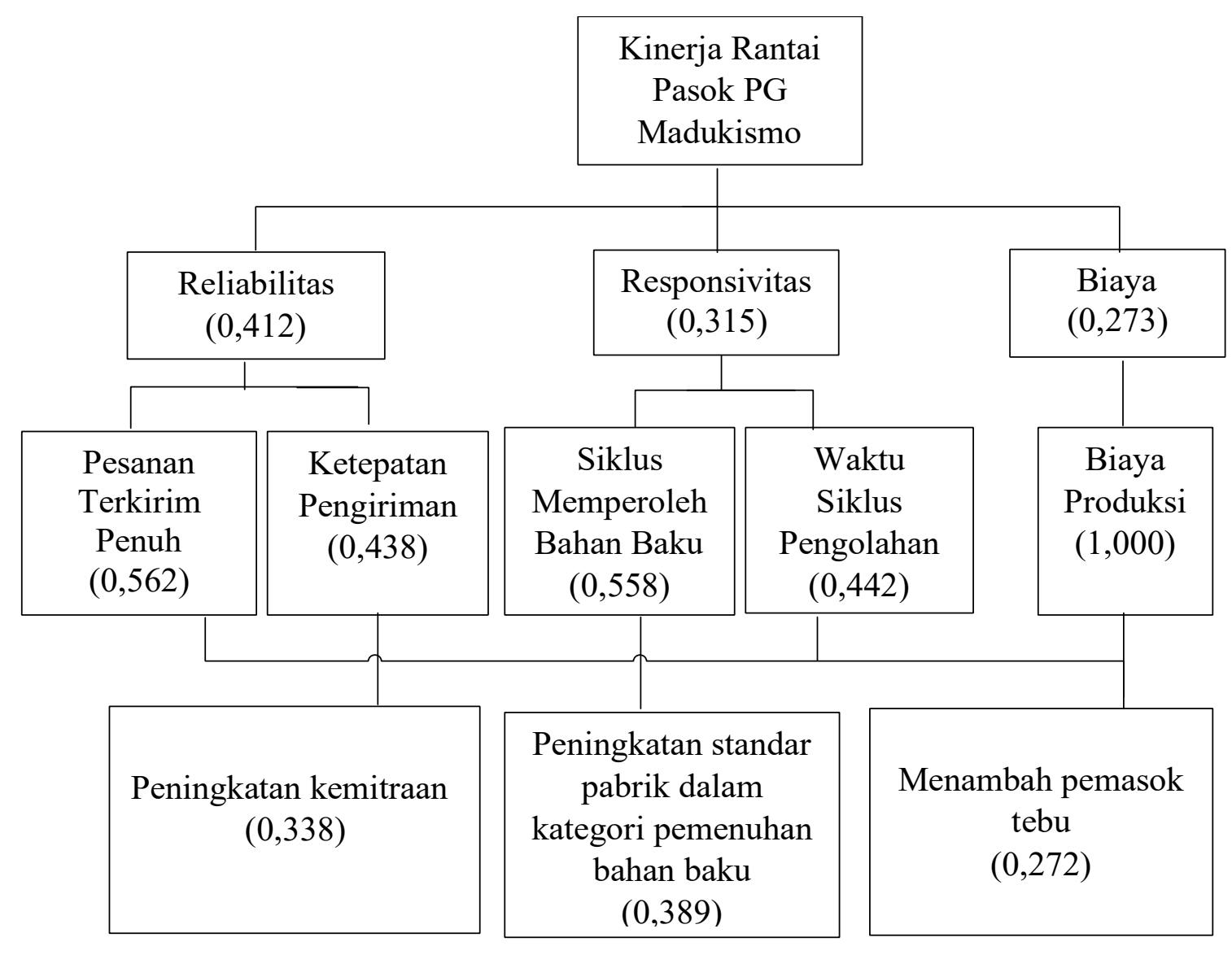

Gambar 2. Hasil Pengukuran Kinerja Rantai Pasok PG Madukismo 
Tabel 3. Kinerja Rantai Pasok di PG Madukismo Tahun 2018

\begin{tabular}{lcl}
\hline $\begin{array}{c}\text { Anggota } \\
\text { Rantai }\end{array}$ & $\begin{array}{c}\text { Hasil } \\
(\%)\end{array}$ & Kategori \\
\hline Petani & 80,82 & Good \\
Pabrik & 93,32 & Excellent
\end{tabular}

Sumber: Data Primer Diolah (2018)

target perusahaan yang kemudian dikalikan dengan bobot AHP. Nilai aktual merupakan persentase dari pencapaian target anggota rantai pasok. Ringkasan hasil pengukuran kinerja rantai pasok di PG Madukismo pada tahun 2018 dapat dilihat pada Tabel 3.

Berdasarkan hasil perhitungan nilai kinerja, dapat diketahui bahwa kinerja petani termasuk dalam kategori Good dan kinerja pabrik dalam kategori Excellent. Nilai kinerja petani yang Good dikarenakan sisklus pemenuhan bahan baku yang lambat. Untuk lahan tebu yang lokasinya jauh dari kebun bibit memerlukan waktu lebih lambat dalam memperoleh bahan baku. Ketepatan pengiriman juga menjadi faktor yang perlu diperhatikan karena tebu harus digiling dalam kondisi segar untuk menjada poin rendemen. Apabila tebu yang dikirimkan sudah lebih dari $2 \times 24$ jam atau tebu terbakar tetap digiling dengan risiko akan mengurangi poin rendemen. Oleh sebab itu, perlu adanya pengaturan jadwal tebang agar tebu yang dipasok ke PG Madukismo masih segar. Pengaturan jadwal tebang juga diperlukan agar petani tidak dapat sembarangan memanen tebu yang akan mengakibatkan penumpukan tebu di ruang tunggu tebu (emplacement).

Nilai kinerja pabrik secara total memang sudah termasuk dalam kategori Excellent. Meskipun demikian kinerja rantai pasok di PG Madukismo belumlah optimal dikarenakan masih terdapat masalah pada kinerja waktu siklus pengolahan. Siklus pengolahan bahan baku yang bermasalah ini disebabkan oleh kapasitas giling pabrik yang turun. Menurunnya kapasitas giling dapat disebabkan oleh adanya mesin yang bermasalah dan perlu perbaikan atau dikarenakan adanya hari libur nasional. Hari libur nasional akan berpengaruh pada ketersediaan tenaga kerja tebang angkut. Jika akan memasuki libur nasional, maka pabrik terpaksa harus menurunkan kapasitas gilingnya agar penggilingan tebu dapat terus berjalan.

Masalah utama yang dihadapi PG Madukismo saat ini adalah kesulitan memperoleh bahan baku dikarenakan semakin minimnya ketersediaan lahan untuk budidaya tebu (persaingan dengan komoditas lain dan alih fungsi lahan), pergeseran atau mundurnya pola tanam, serta semakin mahalnya biaya dan ketersediaan tenaga kerja manusia yang terbatas. Kondisi tersebut mengakibatkan bergesernya budidaya tebu ke lahan tegalan maupun lahan marginal dengan penerapan sistem mekanisasi untuk mengoptimalkan produktivitas tebu. Sejalan hasil penelitian Asrol (2017), adanya pengukuran kinerja rantai pasok dapat dijadikan bahan evaluasi dan proses pengendalian proses bisnis yang dijalankan, karena pengukuran kinerja dengan model SCOR dapat dengan mudah mendeteksi seluruh aktivitas dari proses bisnis.

\section{Alternatif Pengoptimalan Kinerja Rantai Pasok}

Berdasarkan Gambar 2, terdapat tiga alternatif solusi yang disarankan terhadap permasalahan yang dihapai oleh PG Madukismo saat ini, yaitu peningkatan kemitraan, peningkatan standar pabrik dalam pemenuhan bahan baku, dan menambah pemasok tebu. Berdasarkan hasil pembobotan oleh pakar, diperoleh hasil bahwa peningkatan standar pabrik dalam kategori pemenuhan bahan baku menjadi alternatif terpenting yang perlu diperhatikan dengan bobot 0,389 . Hal ini berarti bahwa pabrik perlu meningkatkan standar kualitas tebu yang masuk agar target rendemen dapat tercapai dan pabrik dapat bekerja secara optimal. Semakin baik kualitas tebu yang diperoleh maka semakin banyak gula yang dihasilkan. Berdasarkan Asrol (2015), rendemen merupakan kunci utama 
keberhasilan pengolahan tebu, karena rendemen menandakan semakin efisien kinerja pabrik. Menurut Bantacut (2010), ukuran kinerja pabrik yang paling utama dan penting adalah adalah rendemen. Nilai rendemen dipengaruhi oleh banyak faktor yang salah satunya adalah efisiensi pabrik. Efisiensi pabrik adalah ukuran kemampuan mengambil gula yang ada dalam tebu. Semakin tinggi proporsi gula yang didapat, semakin efisien pabrik.

Alternatif selanjutnya yang cukup penting adalah peningkatan kemitraan dengan bobot 0,338 . Baiknya hubungan dengan mitra akan menciptakan rasa kepercayaan mitra kepada pabrik. Salah satu cara untuk meningkatan kemitraan dengan mitra yang saat ini adalah menawarkan pelayanan prima serta kepedulian sosial kepada mitra PG Madukismo. Pola kerja kemitraan diperoleh PG Madukismo dengan cara mendekati para pamong desa. Tujuannya adalah tanah yang disewakan oleh pamong desa dapat dibudidayakan selama masa jabatan pamong desa tersebut.

Alternatif solusi ketiga adalah menambah pemasok tebu dengan bobot 0,272. Alternatif ini bukan berarti tidak penting, namun pakar menganggap bahwa perluasan areal budidaya tebu dengan pola kerja sama kemitraan lebih diutamakan dibandingkan dengan menambah pemasok tebu mandiri. Hal ini dikarenakan perjanjian kontraktual dengan pola kemitraan lebih menjanjikan ketersediaan tebu daripada perjanjian dengan petani mandiri.

\section{SIMPULAN DAN SARAN}

\section{Simpulan}

Berdasarkan hasil dan pembahasan penelitian diperoleh beberapa kesimpulan bahwa mekanisme rantai pasok dimulai di PG Madukismo terdiri dari (1) struktur rantai pasok yang dimulai dari pengaturan jadwal tebang oleh bagian tanaman hingga penjualan gula oleh bagian pemasaran; (2) proses bisnis berupa sistem bagi hasil dengan persentase $66 \%$ bagian petani dan $34 \%$ bagian $\mathrm{PG}$ Madukismo; (3) sumberdaya rantai pasok berupa kapasitas giling 3.500 TCD serta teknologi budidaya dengan sistem Reynoso dan mekanisasi; (4) manajemen rantai pasok berupa kesepakatan kontraktual dengan petani. Adapun kinerja rantai pasok di $\mathrm{PG}$ Madukismo berdasarkan metode SCOR-AHP secara keseluruhan tergolong baik dengan nilai $80,82 \%$ pada petani (pemasok) dan 93,32\% pada pabrik.

\section{Saran}

Berdasarkan alternatif solusi, PG Madukismo perlu meningkatkan standar pabrik dalam pemenuhan bahan baku dengan cara memperketat aturan dalam standar kategori tebu bersih yang dipasok dan melakukan sortasi agar bahan yang tergiling hanya batang tebu. PG Madukismo juga perlu meningkatkan kerja sama dengan petani tebu pola kemitraan dengan cara mendekati para pamong desa. Tujuannya agar tanah yang disewakan oleh pamong desa dapat dibudidayakan tebu.

\section{DAFTAR PUSTAKA}

Aditya, I. 2019. PG Madukismo Tetap akan Berproduksi. https://krjogja.com/web/ news/read/88300/PG_Madukismo_Tet ap_akan Berproduksi Diakses tanggal 08 Oktober 2019.

Anwar, S. N. 2011. Manajemen rantai pasok (supply chain management): konsep dan hakikat. Jurnal Dinamika Informatika, 3(2). https://www.unisbank.ac.id/ojs/index. php/fti2/article/view/1315 Diakses tanggal 30 September 2019.

Asrol, M. 2015. Pengukuran dan Peningkatan Kinerja Rantai Pasok Agroindustri Gula Tebu (Studi Kasus di PT A). Skripsi. Institut Pertanian Bogor. Bogor.

Asrol, M., Marimin, and Mahfud. 2017. Supply chain performance measurement and improvement for 
sugarcane agro-industry. International Journal of Supply Chain Management 6(3): 8-21.

Bantacut, T. 2010. Swasembada gula: prospek dan strategi pencapaiannya. Pangan 19(3): 245-256.

Ferdiansyah, J. 2012. Budidaya Tebu. Yogyakarta. deeppublish.

Ferrinadewi, E., dan S. P. Djati. 2004. Upaya mencapai loyalitas konsumen dalam perspektif sumber daya manusia. Jurnal Manajemen \& Kewirausahaan 6(1): 15-26.

Hartati, M., D. Efendi dan M. Yola. 2017. Analisis pengukuran kinerja aliran supply chain di PT. Asia Forestama Raya dengan Metode Supply Chain Operation Reference (SCOR). Jurnal teknik Industri 3(2): 94-102.

Heizer, J dan B. Render. 2015. Manajemen Operasi:

Manajemen

Keberlangsungan dan Rantai Pasokan Edisi 11. Jakarta. Salemba Empat.

Kertiyasa, M. B. 2018. Terus Merugi, PTPN X Tutup Pabrik Gula Mereka. https://economy.okezone.com/amp/20 18/02/23/320/1863866/terus-merugiptpn-x-tutup-pabrik-gula-meraka Diakses tanggal 08 Oktober 2019.

Lambert, D. M dan M. C. Cooper. 2000. Issues in supply chain managmenet. Industrial marketing management 29: 65-83.

Marimin dan N. Maghfiroh. 2010. Aplikasi Teknik Pengambilan Keputusan dalam Manajemen Rantai Pasok. Bogor. IPB Press.

Narindra, N. 2015. Analisis kinerja rantai pasok daging ayam di PT BP. Skripsi. Institut Pertanian Bogor. Bogor.
Pertama, Y. R., Nofialdi, dan Kardiman. 2014. Aplikasi metode AHP (Analytical Hierarchy Process) dalam menganalisis indikator kinerja kunci rantai pasok tandan buah segar kelapa sawit di PT XYZ. Jurnal Agribisnis Kerakyatan 4(1): 12-24.

Rofik, M. A. 2010. Kinerja rantai pasok pada industri seafood (studi kasus di PT. Kelola Mina Laut, Gresik). Skripsi. Institut Pertanian Bogor. Bogor.

Safirin, M. 2005. Analisis kinerja pada supply chain perusahaan gula. Seminar Nasional Implementasi Supply Chain Management and Logistics dalam bidang Industri. Universitas Pembangunan Nasional Jawa Timur, Surabaya, 29 September 2005. p. 6169.

Sumiati. 2007. Pengukuran performansi supply chain perusahaan dengan pendekatan Supply Chain Operations Reference (SCOR) di PT Madura Guano Industri (Kamal-Madura). Journal of Industrial Engineering and Management 2.

Supriyatna, I. 2017. 23 Pabrik Gula Milik PTPN Bakal Ditutup. https://amp.kompas.com/money/read/ 2017/03/09/201143626/23.pabrik.gula .milik.ptpn.bakal.ditutup Diakses tanggal 08 Oktober 2019. 